\title{
Kursi Ergonomis Untuk Menurunkan Kelelahan Tenaga Kerja SPBU Berdasarkan Fluktuasi Asam Laktat dan Glukosa Dalam Darah
}

\author{
Oleh: Gempur Santoso *)
}

\begin{abstract}
Abstrak
Tenaga kerja Stasiun Pengisian Bahan Bakar Umum (SPBU) bekerja terus menerus dan lama, posisi kerja seperti itu sangat melelahkan. Populasi penelitian ini adalah operator SPBU di Kota Surabaya. Besar sampel penelitian 11 orang terdiri laki-laki 6 orang dan perempuan 5 orang. Usia responden berkisar 20 tahun sampai dengan 36 tahun.

Terdapat dua kelompok penelitian yakni kelompok $A$ bekerja posisi berdiri tegak, dan kelompok B bekerja posisi berdiri setengah duduk dengan memakai kursi ergonomis. Data penelitian diambil dengan mengukur konsentrasi asam laktat dan glukosa dalam darah setelah kerja secara laboratories. Analasis data dilakukan secara deskriptif kualitatif.

Kesimpulan: tenaga kerja SPBU menggunakan kursi ergonomis posisi kerja berdiri setengah duduk lebih tidak melelahkan (nyaman) 2,17 \% (selisih asam laktat 0,03 mmol/L) dibanding posisi berdiri tegak, energy tubuh masih lebih banyak 4,22 \% (selisih glukosa 3,83 $\mathrm{mg} / \mathrm{dL}$ ) dibanding posisi berdiri tegak. Saran: agar tenaga kerja SPBU tidak lagi bekerja posisi berdiri secara terus menerus, perlu duduk di kursi ergonomis menghadap pompa bahan bakar minyak (BBM),
\end{abstract}

Kata Kunci: posisi berdiri tegak, posisi berdiri setengah duduk, kelelahan, asam laktat, glukosa, kursi ergonomis, tenaga kerja SPBU.

\section{PENDAHULUAN}

Bekerja dengan performen berdiri statis dalam waktu yang lama memang cepat melelahkan bagian otot tulang belakang (vertebral) daripada otot kaki. Seperti tenaga kerja Stasiun Pengisian Bahan Bakar Umum (SPBU) yang bekerja terus menerus berdiri selama lebih kurang 8 jam, performen kerja seperti itu sangat melelahkan.

Posisi kerja berdiri tidak ergonomis dapat menimbulkan kelelahan, nyeri, dan gangguan kesehatan lainnya. Sebagaimana Yassierli et.al. (2000) yang meneliti "tenaga kerja di industri permesinan konvensional menengah dengan fokus stasiun kerja bubut, las, press, gerinda, drill, milling dan potong manual. Pekerjaan tersebut dilakukan dengan performen berdiri. Dari 24 responden mengalami keluhan berupa kelelahan biomekanik terbanyak pada bahu kanan 20 orang dan pinggang 18 orang".

Sebagaimana hasil penelitian Gempur (2008) "perubahan kerja performen berdiri tegak (TG), menjadi performen berdiri setengah duduk tanpa sandaran (SDTS), dan berdiri setengah duduk pakai sandaran (SDPS) berpengaruh terhadap tingkat kelelahan kerja berdasar respons konsentrasi asam laktat dan glokusa secara signifikan, koefisien respons asam laktat dan glukosa dari posisi berdiri TG (laktat:4,853 $\mathrm{mmol} / \mathrm{kg}$, glukosa: $0,221 \mathrm{mg} \%$ ) pada posisi SDTS turun menjadi (laktat: $3,100 \mathrm{mmol} / \mathrm{kg}$, glukosa: $0,175 \mathrm{mg} \%$ ) dan SDPS menjadi (laktat: $3,314 \mathrm{mmol} / \mathrm{kg}$, glukosa: 0,07089 $\mathrm{mg} \%)$. Hal itu menunjukkan bahwa kerja performen berdiri TG lebih melelahkan dibanding SDTS maupun SDPS. Oleh karena itu, sebaiknya hindarkan kerja posisi berdiri tegak-statis dan ubah menjadi kerja performen berdiri setengah duduk.

Poosisi kerja yang berdiri terusmenerus dan lama tidak membuat relaksasi pada otot rangka (skeletal muscle), terutama pada otot erector. Otot erector merupakan salah satu otot utama yang menahan otot tulang belakang (vertebral) agar tidak membungkuk. Otot erector akan relaksasi ketika disandarkan, dan otot kaki akan relaksasi ketika duduk. Apakah operator SPBU juga mengalami kelelahan, dan seberapa besar tingkat kelelahan yang diterimanya ketika melakukan pekerjaannya?

\footnotetext{
*) Dosen Teknik Industri

Universitas PGRI Adi Buana Surabaya
} 


\section{METODE PENELITIAN}

Populasi penelitian ini adalah operator SPBU di Kota Surabaya. Sedangkan sampelnya adalah 12 tenaga kerja terdiri atas 6 orang laki-laki dan 6 orang perempuan. Karena 1 orang perempuan berhalangan maka tinggal 5 orang. Cara pengambilan sampel adalah secara kriteriarandom pada tenaga kerja SPBU di kota Surabaya. Usia responden berkisar 20 tahun sampai dengan 36 tahun yakni masih dalam batas usia produktif ( $<40$ tahun).

Data penelitian diambil dengan mengukur konsentrasi asam laktat dan glukosa dalam darah setelah kerja secara laboratories. Analisis data dilakukan secara komparasi deskriptif-kualitatif.

\section{HASIL PENELITIAN DAN PEMBAHASAN}

\section{A. Kelelahan Tenaga Kerja SPBU Berdasarkan Asam Latat dan Glukosa}

Konsentrasi asam latat dan glukosa dalam darah setelah bekerja 4 jam terus menerus pada tenaga kerja SPBU. Posisi berdiri tegak (lihat gambar 1), selanjutnya hasil pengukuran konsentrasi asam laktat dan glukosa dapat dilihat pada tabel 1. Pada tabel 1 tersebut menunjukkan bahwa tenaga kerja SPBU posisi berdiri tegak setelah kerja rata-rata kosentrasi asam laktat dalam darah $1,38 \mathrm{mmol} / \mathrm{L}$ dan glukosa dalam darah 87,00 $\mathrm{mg} / \mathrm{dL}$.

\section{Tabel 1. Konsentrasi Asam Latat dan Glukosa Tenaga Kerja SPBU Posisi Kerja Berdiri Tegak}

\begin{tabular}{|l|l|c|c|}
\hline \multirow{2}{*}{ No } & Nama & \multicolumn{2}{|c|}{ 4 Jam Setelah Kerja } \\
\cline { 3 - 4 } & & $\begin{array}{c}\text { Asam Laktat } \\
\text { (mmol/L) }\end{array}$ & $\begin{array}{c}\text { Glukosa } \\
\text { (mg/dL) }\end{array}$ \\
\hline 1 & OKT & 1,20 & 85 \\
2 & DEW & 2,10 & 67 \\
3 & JK & 1,50 & 98 \\
4 & DEWB & 1,10 & 94 \\
5 & JKB & 1,00 & 91 \\
\hline \multicolumn{2}{|l|}{ JML } & $\mathbf{6 , 9 0}$ & $\mathbf{4 3 5}$ \\
\hline \multicolumn{2}{|l|}{ RERATA } & $\mathbf{1 , 3 8}$ & $\mathbf{8 7 , 0 0}$ \\
\hline
\end{tabular}

Kemudian, posisi kerja berdiri setengah duduk (gambar 2), selanjutnya hasil pengukuran konsentrasi asam laktat dan glukosa dapat dilihat pada tabel 2. Pada tabel 2 tersebut menunjukkan bahwa tenaga kerja SPBU posisi berdiri setengah duduk setelah kerja rata-rata kosentrasi asam laktat dalam darah $1,35 \mathrm{mmol} / \mathrm{L}$ dan glukosa dalam darah
90,83 $\mathrm{mg} / \mathrm{dL}$.

Tabel 2. Konsentrasi Asam Latat dan Glukosa Tenaga Kerja SPBU

Posisi Kerja Berdiri Setengah Duduk

\begin{tabular}{|l|l|c|c|}
\hline No & Nama & \multicolumn{2}{|c|}{ 4 Jam Setelah Kerja } \\
\cline { 3 - 4 } & Asam Laktat & $\begin{array}{c}\text { Glukosa } \\
\text { (mg/dL) }\end{array}$ \\
\hline 1 & RKP & 1,40 & 104 \\
2 & ID & 1,30 & 88 \\
3 & DW & 1,00 & 80 \\
4 & AZZ & 1,20 & 84 \\
5 & ANG & 1,50 & 100 \\
6 & FTR & 1,70 & 89 \\
\hline \multicolumn{2}{|l|}{ JML } & $\mathbf{8 , 1}$ & $\mathbf{5 4 5}$ \\
\hline \multicolumn{2}{|l}{ RERATA } & $\mathbf{1 , 3 5}$ & $\mathbf{9 0 , 8 3}$ \\
\hline
\end{tabular}

Berdasarkan tabel 2 dan tabel 1 di atas, selisih asam latat dalam darah pada tenaga kerja SPBU posisi kerja berdiri setengah duduk dan berdiri tegak, untuk asam laktat $(1,35 \mathrm{mmol} / \mathrm{L}-1,38 \mathrm{mmol} / \mathrm{L}=$ -
$0,03 \mathrm{mmol} / \mathrm{L}$ posisi berdiri setengah duduk lebih kecil dibanding berdiri tegak), untuk glukosa $(90,83 \mathrm{mg} / \mathrm{dL}-87,00 \mathrm{mg} / \mathrm{dL}=3,83$ $\mathrm{mg} / \mathrm{dL}$ posisi setengah duduk lebih besar dibanding berdiri tegak). Hal tersebut 
menunjukkan bahwa kosentrasi asam latat setelah kerja pada tenaga kerja SPBU posisi berdiri setengah duduk lebih rendah 0,03 $\mathrm{mmol} / \mathrm{L}(2,17 \%)$ dibanding posisi berdiri tegak, kandungan berupa glukosa dalam darah posisi berdiri setengah duduk masih lebih banyak $3,83 \mathrm{mg} / \mathrm{dL}(4,22 \%)$ dibanding posisi berdiri tegak. Dengan demikian dapat

Asam laktat dan glukosa dapat digunakan untuk mendeteksi kelelahan kerja. Sebagaimana hasil penelitian Santoso (2008) menyimpulkan bahwa "respons konsentrasi asam laktat dan glukosa dapat dipakai sebagai paremeter deteksi kelelahan kerja". Hal itu senada hasil penelitian Anna, 1994; Guyton et.al., 1997 menyebutkan bahwa "peningkatan asam laktat menimbulkan rasa lelah, dan kelelahan otot meningkat berbanding langsung dengan penurunan glikogen otot".

Dari data pendukung yakni data kelelahan subjektif secara umum tenaga kerja SPBU kerja posisi berdiri tegak dapat dilihat pada tebel 3 berikut ini.

\section{Tabel 3. Kelelahan subjektif tenaga kerja SPBU posisi berdiri tegak}

\begin{tabular}{|l|l|l|}
\hline No. & Pernyataan & Persentase \\
\hline 1. & Merasa lelah & $29,09 \%$ \\
2. & Merasa tidak lelah & $70,91 \%$ \\
\hline
\end{tabular}

Kerja posisi berdiri tegak seperti operator SPBU (lihat gambar 1) lebih banyak melibatkan intensitas kontraksi otot akan membutuhkan energi yang banyak. Penyediaan energi tersebut diperoleh melalui pemecahan adenosin trifospat (ATP) melalui proses metabolisme energi anaerobik (MEA). "Dalam metabolisme respirasi anaerob hasil terbanyak reduksi piruvat adalah asam laktat" (Becker et.al., 1999; Peter, 1999).

Ketika intensitas kerja otot meningkat, maka pasokan oksigen tidak mencukupi. Dalam kondisi seperti itu, dibutuhkan tambahan ATP disediakan melalui MEA. MEA tersebut menyebabkan konsentrasi asam laktat meningkat dan glikogen menurun. Dalam MEA predominan tersebut, kreatinfosfat tetap digunakan untuk sintesis ulang ATP. Sebagian sintesis ATP dipenuhi dengan menggunakan energi yang dilepaskan melalui penguraian anaerobik glukosa menjadi laktat. Sebagaimana pendapat Becker et al. (1999) bahwa "ketika anaerobik cadangan piruvat digunakan elektron aseptor untuk NADH menjadi $\mathrm{NAD}^{+}$, diartikan bahwa tenaga kerja SPBU poisisi berdiri setengah duduk lebih tidak melelahkan yakni konsentrasi asam laktatnya lebih rendah 2,217 \% dibanding kerja posisi tegak, dan kosentrasi energi berupa glukosa masih lebih banyak sebesar $4,22 \%$ dibanding kerja posisi berdiri tegak.

oleh karena itu terjadi regenerasi oksidasi koenzim reaksi Gly 6 pada glikolisis. Hasil terbanyak dari reduksi piruvat adalah laktat". Jadi selama glikolisis, banyak glukosa diurai hasil terbanyak dari reduksi tersebut adalah piruvat dan asam laktat dalam otot skelet.
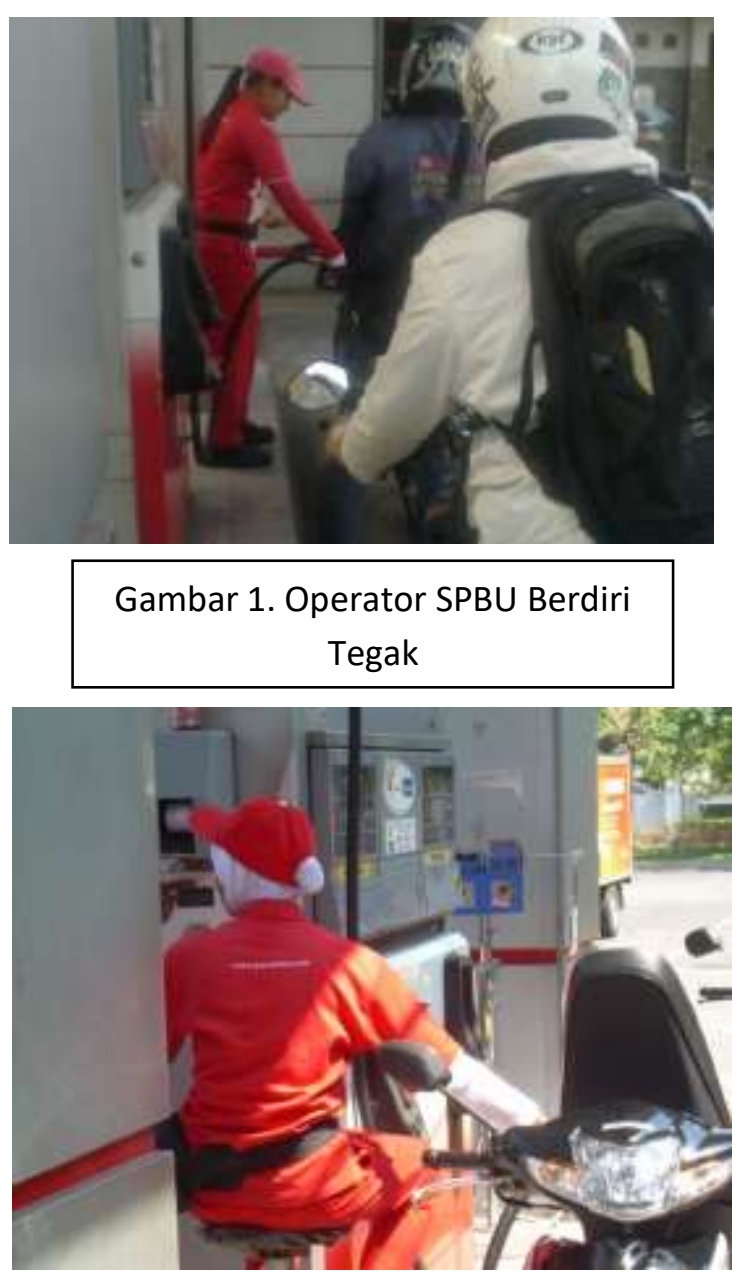

Gambar 2. Operator SPBU Berdiri Setengah Duduk

Selanjutnya, hasil metabolisme karbohidrat antara lain glukosa. Glukosa terdapat dalam darah dapat ditimbun dalam sel yang berupa polimer glukosa atau glikogen. Menurut Peter (1999) bahwa "sebagian karbohidrat makanan dikonversi menjadi lemak dan akibatnya dimetabolisis sebagai lemak". Oleh karena itu, dalam 
suatu kegiatan yang membutuhkan kontraksi otot, sumber energi tubuh dapat diperoleh dari tiga sumber, sebagaimana menurut Becker et al. (1999) yakni dari "glukosa dalam darah, timbunan glikogen dalam sel hati dan otot rangka, dan simpanan triasilgliserol (lemak) di jaringan adiposa".

\section{KESIMPULAN DAN SARAN}

\section{A. Kesimpulan,}

1. Tenaga kerja SPBU menggunakan kursi ergonomis poisisi kerja berdiri setengah duduk lebih tidak melelahkan yakni konsentrasi asam laktat dalam darah lebih rendah $2,217 \%$ dibanding kerja posisi berdiri tegak, dan kosentrasi energi berupa glukosa masih lebih banyak sebesar 4,22\% dibanding kerja posisi berdiri tegak. Hal tersebut ditunjukkan dari kosentrasi asam laktat setelah kerja pada tenaga kerja SPBU posisi berdiri setengah duduk lebih rendah $0,03 \mathrm{mmol} / \mathrm{L}$ $(2,17 \%)$ dibanding posisi berdiri tegak, kandungan berupa glukosa dalam darah posisi berdiri setengah duduk masih lebih banyak 3,83 $\mathrm{mg} / \mathrm{dL} \quad(4,22 \%)$ dibanding posisi berdiri tegak.

\section{B. Saran}

1. Agar tenaga kerja SPBU tidak lagi bekerja posisi berdiri secara terus menerus perlu diberikan kursi ergonomis.

2. Tenaga kerja SPBU untuk posisi kerja berdiri setengah duduk sebaiknya menggunakan kursi ergonomis diletakan pada pada sisi samping pompa BBM, jadi pompa BBM di depan operator (tenaga kerja) dan kendaraan sepeda motor yang mengisi BBM terletak pada sisi kanan operator.

\section{DAFTAR PUSTAKA}

Anna Poedjiadi, Dasar-dasar biokimia, UI-Press, Jakarta, 1994:274-275.

Becker M. Wayne, Jane B. Reece and Martin F. Poenie, The world of the cell, Third edition, The Benjamin/comings publishing company, 1999: 296-325.

Ethel Slonane, Anatomi dan Fisiologi Pemula, Catakan I, EGC, 2004:150

Ganong F, William, Fisiologi Kedokteran, EGC, Edisi 17, !977

Gempur Santoso, Deteksi Kelelahan pada kerja bubut posisi berdiri terhadap fluktuasi asam laktat dan glukosa, Wahana volume 51 no. , Juni 2008: 19-26.

Guyton C. Arthur \& Hall E. John, Fisiologi kedokteran (textbook of medical physiology), EGC, 1997: 91-105.

Nederhand J. Marc, Cervical muscle dysfunction in the chronic whiplash associated grade II (WAP II), Spine Vol. 25, 2000: 1938-1943.

Peter A. Mayes, Glikolisis dan oksidasi piruvat, Biokimia Harper, Edisi 24, EGC, Jakarta, 1999: 181-189.

Totok Budi Santoso, Pengaruh posisi kerja terhadap timbulnya nyeri punggung bawah pada pengrajin rotan di desa Trangsan kabupaten Sukoharjo, Infoke Vol 8 no 1 - Maret September 2004.

Thompson W, Clem, Manual of structural kinesiology, The CV. Mosby company, Ninth edition, London, 1981: 3-25, 111, dan 122-123.

Yassierli, Iftikar Z. Sutalaksana, Evaluasi dan analisis postur kerja dalam sistem kerja permeinan konvensional Indonesia, Proceeding Seminar Nasional Ergonomi 2000 (162-166). 